Riccardo Pozzo

History of Philosophy and the Reflective Society 

Riccardo Pozzo

History of Philosophy

and the Reflective

Society

DE GRUYTER 
The Open Access of this book was financially supported by the Alexander von Humboldt Foundation and the Department of History, Humanities, and Society of Tor Vergata University of Rome as an output of the H2020 funded project Cross-Migration (GA 770121).

Unterstūtzt von / Supported by

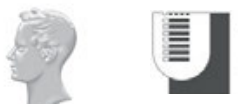

\section{Alexander von Humboldt}

Stiftung/Foundation

ISBN 978-3-11-070905-6

e-ISBN (PDF) 978-3-11-070929-2

e-ISBN (EPUB) 978-3-11-070933-9

DOI https://doi.org/10.1515/9783110709292

\section{(cc) BY-NC-ND}

This work is licensed under the Creative Commons Attribution-NonCommercial-NoDerivatives 4.0 International License. For details go to https://creativecommons.org/licenses/by-nc-nd/4.0/.

Library of Congress Control Number: 2021942121

\section{Bibliographic information published by the Deutsche Nationalbibliothek}

The Deutsche Nationalbibliothek lists this publication in the Deutsche Nationalbibliografie; detailed bibliographic data are available on the Internet at http://dnb.dnb.de.

(C) 2021 Riccardo Pozzo, published by Walter de Gruyter GmbH, Berlin/Boston. The book is published with open access at www.degruyter.com.

Printing and binding: $\mathrm{CPI}$ books $\mathrm{GmbH}$, Leck

www.degruyter.com 